\title{
Dynamics of nitrate and nitrite in saturated sand filters with enhanced substrate conditions for denitrifying bacteria
}

\author{
Rasha Al-Saedi ${ }^{\mathrm{a}, \mathrm{b}, \mathrm{c}, *}$, Keith Smettem ${ }^{\mathrm{c}, \mathrm{d}}$, Katia Stefanova ${ }^{\mathrm{c}, \mathrm{e}}$, Kadambot H.M. Siddique \\ ${ }^{a}$ Department of Civil, Environmental, and Mining Engineering, The University of Western Australia, Perth, WA 6001, \\ Australia, email: Rasha.az2013@gmail.com \\ ${ }^{b}$ Department of Environmental Engineering, Mustansiriya University, Baghdad, Iraq \\ 'The UWA Institute of Agriculture, The University of Western Australia, Perth, WA 6001, Australia, \\ emails: keith.smettem2@murdoch.edu.au (K.Smettem),katia.stefanova@uwa.edu.au (K. Stefanova), \\ kadambot.siddique@uwa.edu.au (K.H.M. Siddique) \\ ${ }^{d}$ College of Science, Health, Engineering and Education, Murdoch University, Perth, WA 6150, Australia \\ 'School of Molecular and Life Sciences, Curtin University, Perth, WA 6845, Australia
}

Received 17 May 2020; Accepted 28 September 2020

\section{A B S T R A C T}

Substrate conditions for denitrifying bacteria were enhanced by adding carbon sources to a laboratory-scale sand filter system. Temperature, oxidation-reduction potential, and hydrogen ion concentration were measured through the recirculation of nitrogen-dosed wastewater and carbon sources that were mixed to encourage microbial growth, with denitrifying bacteria identified by standard plate counts. Two different external carbon sources (sucrose and ethanol) were added, with and without activated sludge amendments. Nitrate, nitrite, and chemical oxygen demand (COD) concentrations were monitored relative to an untreated control and a treatment with activated sludge under an initial hydraulic loading rate of $0.508 \mathrm{~m}^{3} / \mathrm{m}^{2} \mathrm{~d}$ and a hydraulic retention time of $2.5 \mathrm{~h}$. Nitrate decay rates were only significantly enhanced for the ethanol treatment without addition of activated sludge. Nitrite initially accumulated when carbon sources were added, but no accumulation was evident by the end of the experiment after $150 \mathrm{~min}$. COD declined when carbon sources were added, but activated sludge had no effect on the rate at which the COD declined. The increased rate of nitrate removal with the addition of ethanol is of technical interest, as the volume of wastewater treated in a unit volume of filter medium for denitrification doubled with ethanol compared with sucrose at the same concentration.

Keywords: Nitrate; Nitrite; Chemical oxygen demand; Saturated sand filters; Denitrification

\section{Introduction}

High nitrate concentrations in drinking water have been linked to both methemoglobinemia and bladder cancer. Furthermore, treated municipal wastewater that contains high amounts of nitrate can enter water bodies and potentially stimulate algal blooms, degrade water quality, and reduce biological diversity. This eutrophic phenomenon is the major cause of the hypoxic zone "dead zone" in water [1]. Nitrite accumulation (an intermediate product of nitrate reduction during the denitrification process) is not beneficial in wastewater treatment as extra oxygen for $\mathrm{N}$

* Corresponding author. 
removal is required. Furthermore, there can be problems associated with discharging of wastewater into natural water bodies without treating nitrite [2]. Glass and Silverstein [3] reported that nitrite accumulation could inhibit denitrification because it hinders bacterial development.

Denitrification is a progressive reaction converting nitrate to nitrogen gas by enhancing indigenous denitrifying microorganisms [4]. Cui et al. [5] reported no clear difference in nitrate removal between planted and unplanted sand filters. Thus, we highlighted in this experiment the role of adding different $C$ sources such as ethanol and sucrose (external $C$ sources) and activated sludge (internal $C$ sources) in unplanted sand filters. The addition of external $\mathrm{C}$ sources and internal $C$ sources to the filter material has been considered a stable source of carbon for denitrifying bacteria, potentially enhancing nitrogen removal and reducing the hydraulic retention time and the treatment area required per unit volume of wastewater and thus reducing treatment costs [6-9]. Ethanol and sucrose have often been the choice in practice as they are cheap and convenient $[6,10]$.

Constantin and Fick [11], Dold et al. [12], Gomez et al. [13], Hallin and Pell [14], Rodriguez-Caballero et al. [15] have worked with ethanol on denitrification. Few authors have worked with sucrose as a carbon source. Gomez et al. [7], Dold et al. [12], Gomez et al. [13], Hallin and Pell [14], Shah and Coulman [16], Stensel et al. [17] have used activated sludge to stimulate denitrifiers, in addition to the carbon sources and nutrients. A few studies have not used activated sludge as an inoculum, relying only on the contribution of the carbon sources along with the main nutrient substrates $[18,19]$. However, there is a paucity of information on whether adding activated sludge to the main substrate media can further enhance microbial activity to accelerate mass nitrogen removal. Furthermore, no investigation has compared sucrose and ethanol saturated with $\mathrm{N}$ compounds with and without activated sludge.

A review by Mohseni-Bandpi et al. [20] covered the applications of $\mathrm{C}$ sources on $\mathrm{N}$ removal in bioreactors, but not in sand filters. A sand filter system also provides a simplified analogue for saturated flow in groundwater and near-stream riparian zones as well as wetland sediments [21]. Al-Saedi et al. [22] showed that downflow saturated conditions were preferable to unsaturated conditions for mass nitrogen removal, as the final concentrations are similar between the saturated and unsaturated zone. It was, therefore, advantageous to save space and operate this filter bed as an entirely saturated system, as the measured saturated water content was seven times greater than the measured water content of the unsaturated zone. Furthermore, operating a sand filter in an upflow mode can give greater displacement of entrapped air than is possible in the downflow mode, which could provide a preferable condition for denitrification [15]. Therefore, we now seek to establish if removal rates can be accelerated by addition of organic sources to upflow saturated sand filters.

The aims of the study were to: (1) examine how biodegradation of the external $\mathrm{C}$ sources (ethanol and sucrose) is influenced by the internal C source (AS) and how this interaction affects the denitrification rate; (2) assess the behaviour of denitrifiers in sand filters treating nitrate enriched wastewater.

\section{Materials and methods}

\subsection{Experimental setting, sampling and design}

This study used six parallel perspex vertical upflow columns. The column bases had plastic filters to support the sand layer and evenly percolate the wastewater through the columns. The characteristics of the sand columns used in the experiments are given in Table 1.

To enhance nitrate removal under fully saturated conditions in the vertical flow filters, we applied the following steps in the laboratory: (1) initial upflow of wastewater through the core bases to uniformly distribute treated water through the filters; and (2) addition of different liquid organic carbon sources (ethanol and sucrose) with and without activated sludge.

Prior to commencing the experiment, indigenous microorganism activity was stimulated by feeding the system with the nitrate-enriched synthetic wastewater once a week for 3 weeks [23] (the flow was not continuous) as an adaptation period at an influent flow rate and a hydraulic loading rate of $0.003 \mathrm{~m}^{3} / \mathrm{d}$ and $0.508 \mathrm{~m}^{3} / \mathrm{m}^{2} \mathrm{~d}$, respectively. Synthetic wastewater was prepared using potassium nitrate as the only source of nitrate. Two columns were used as controls (CONT) with only $\mathrm{KNO}_{3}$ added, two columns had liquid sucrose added (SUC), and two columns had ethanol added (ETH) at C:N ratios of 5 for SUC and ETH.

Nitrate reduction using ethanol and sucrose as carbon sources is represented in the following stoichiometric reactions $[11,13]$ :

$$
\begin{aligned}
& \mathrm{C}_{12} \mathrm{H}_{22} \mathrm{O}_{11}+9.6 \mathrm{NO}_{3}^{-}+9.6 \mathrm{H}^{+} \rightarrow 12 \mathrm{CO}_{2}+4.8 \mathrm{~N}_{2}+15.8 \mathrm{H}_{2} \mathrm{O} \\
& 5 \mathrm{C}_{2} \mathrm{H}_{5} \mathrm{OH}+12 \mathrm{NO}_{3}^{-} \rightarrow 6 \mathrm{~N}_{2}+10 \mathrm{HCO}_{3}^{-}+2 \mathrm{OH}^{-}+9 \mathrm{H}_{2} \mathrm{O}
\end{aligned}
$$

At the end of the adaptation period, the recirculated wastewaters were completely flushed from the columns. This was followed by an investigation period with a controlled upward flow from a header tank at an influent flow rate and a hydraulic loading rate of $0.003 \mathrm{~m}^{3} / \mathrm{d}$ and $0.508 \mathrm{~m}^{3} / \mathrm{m}^{2} \mathrm{~d}$, respectively. The investigation period involved two operating periods. In the first operating period, the columns were saturated from below with a new synthetic wastewater (the same as flushed). Once saturated, the flow was switched off and denitrification allowed to progress under static, saturated conditions. During the adaptation and investigation periods, a positive head was kept to drive the filter solution out for sampling. Sampling was undertaken by re-establishing the flow briefly at 10, 20, 30, 50, 70, 90, 120 and $150 \mathrm{~min}$ (until nitrate concentrations reached close to zero) to force about $10 \mathrm{~mL}$ of wastewater to accumulate at the soil surface for sampling by syringe (Fig. 1).

In the second operating period, the flushed columns were fed with the same synthetic wastewater described previously (CONT, SUC and ETH), but with $4 \mathrm{~g} / \mathrm{L}$ of mixed liquor activated sludge/L wastewater added. Thus, the second period involved two columns with $\mathrm{KNO}_{3}(\mathrm{CONT})$ and activated sludge (CONT + AS), two columns with liquid sucrose added with activated sludge (SUC + AS), and two columns with ethanol added with activated sludge $(\mathrm{ETH}+\mathrm{AS})$ at the same $\mathrm{C} / \mathrm{N}$ ratio. 
Table 1

Column characteristics

\begin{tabular}{ll}
\hline Parameters & Values and units \\
\hline Column height & $34 \mathrm{~cm}$ \\
Internal diameter & $6 \mathrm{~cm}$ \\
Surface area & $28.26 \mathrm{~cm}^{2}$ \\
Height of coarse sand bed & $16 \mathrm{~cm}$ \\
Volume of coarse sand bed & $452 \mathrm{~cm}^{3}$ \\
Average coarse sand diameter & $0.7 \mathrm{~mm}$ \\
Dry bulk density & $1.33 \mathrm{~g} / \mathrm{cm}^{3}$ \\
Average sand bed porosity & $50 \%$ \\
Average column pore volume & $225 \mathrm{~mL}$ \\
Organic matter content & $0.3 \%$ \\
\hline
\end{tabular}
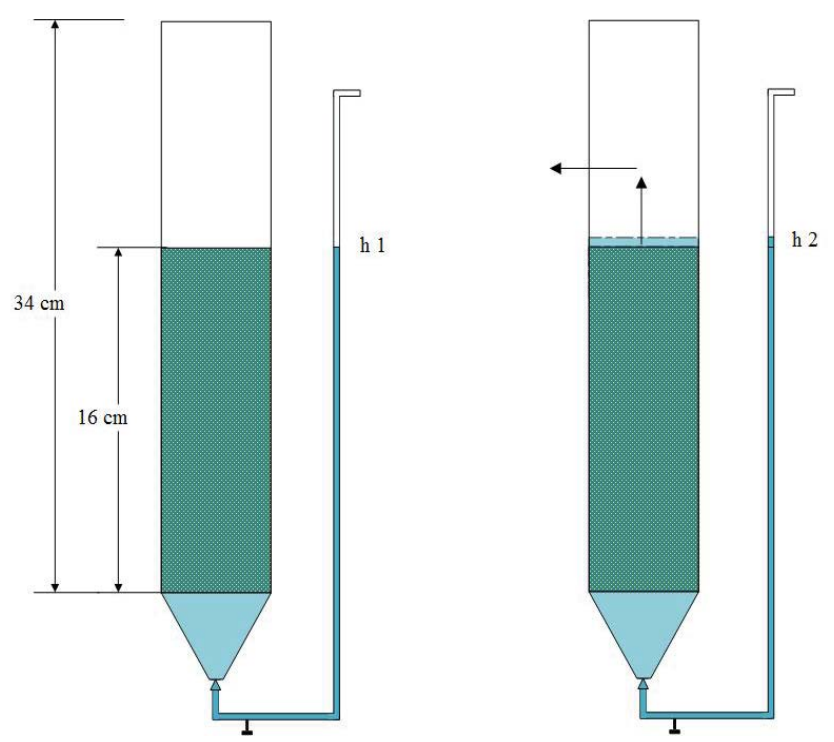

Fig. 1. Schematic diagram of the sampling procedure for one laboratory-scale vertical flow sand filter. h1: hydraulic head before sampling, h2: hydraulic head through sampling, so $h 1-h 2=\Delta h$.

The treatment procedure was repeated twice for each column. Before repeating the treatment, the sand beds were sterilised and repacked, applying the same procedure of recirculating and feeding for each column. The activated sludge was supplied from a wastewater treatment plant with total inorganic nitrogen compounds of $7 \mathrm{mg} / \mathrm{L}$ and total nitrogen of $56.3 \mathrm{mg} / \mathrm{L}$ to give an organic nitrogen concentration of $49.3 \mathrm{mg} / \mathrm{L}$.

As described above, all measurements were taken during the operating period, giving four replicates. At each stage, three treatments were randomly allocated to two columns and sample was taken from each column. In order to account for potential laboratory measurement error, samples were taken in triplicate. After each stage, the columns were repacked, therefore the replicates (columns) can be considered independent and the experimental design can be described as a randomised complete block design.

\subsection{Analytical measurements}

The temperature was measured using an OxyGuard Handy Polaris 2 meter. Oxidation-reduction potential (redox) and hydrogen ion concentration $(\mathrm{pH})$ were measured using a water quality probe $\mathrm{WP} / 81$. For $\mathrm{NO}_{3}$ and $\mathrm{NO}_{2}$ concentrations, the drawn wastewater samples were filtered through $0.45 \mu \mathrm{m}$ membrane filters (Millipore HVLP04700) and then analysed with a HACH DR/6000 spectrophotometer (USA) using HR Ferrous sulphate and HR Cadmium reduction methods for nitrite and nitrate tests respectively.

Organic matter content of the sand was determined by loss on ignition, which is the difference in the dry weight of the ignited sample and the heated sample divided by the heated sample. Chemical oxygen demand (COD) tests were performed in triplicate for each sample using the digestion method with a HACH DR/6000 spectrophotometer (USA).

\subsection{Standard quantification of denitrifying bacteria}

Denitrifying bacteria were quantified by a standard plate count, which is often used in estimating viable bacterial cells in water [24]. This method used nitrate sucrose agar medium as described by Rodina, 1972 [25]. The $\mathrm{pH}$ of the agar medium (Table 2) was adjusted each time to 7.0 by adding small spikes of sodium bicarbonate. During the adaptation period ( $21 \mathrm{~d}), 1 \mathrm{~g}$ of soil was transferred-using a sterilised spoon-from the anoxic zone to a sterile glass bottle containing $100 \mathrm{~mL}$ of $0.9 \% \mathrm{NaCl}$. The soil samples underwent sonication for $5 \mathrm{~min}$ to separate the biofilm from the inert substrate. A dilution series (1:10) with $10 \mathrm{~mL}$ Pyrex tubes was made using a sterile saline solution $(0.9 \% \mathrm{NaCl})$. $0.1 \mathrm{~mL}$ was extracted from each dilution and spread on the prepared medium in Petri dishes, with three replicates for each dilution. The dishes were incubated anaerobically using AnaeroGen system OXOID $\left(28^{\circ} \mathrm{C}-30^{\circ} \mathrm{C}\right)$ for 2 weeks. The number of bacteria (CFU) per gram of sample was calculated on plates of the series displaying 10 to $100 \mathrm{CFU}$.

\subsection{Statistical analysis}

The nitrate decay data were analysed using treatment as a grouping factor in the fitted exponential nonlinear regression to investigate the consistency of a nonlinear relationship across the six treatments. We specifically sought to determine whether treatments had a significant effect on the response, assuming that nitrate concentration declines exponentially with time. The fitted model tested whether the rates and curvature of the fitted curves differ in response to the treatments.

An exponential curve, as formulated below, demonstrated the best fit

$y=y_{0}+b e^{k t}$

where $y_{0}, b$ and $k(k<0$ for exponential decay and $k>0$ for exponential growth) are the parameters and the explanatory variable $t$ is the time when the measurements of nitrate concentration were taken. The statistical significance of the differences between the treatments for peak $\mathrm{NO}_{2}$ concentration and production rate was tested. 
Some additional statistical analyses were conducted using ANOVA techniques for factorial treatment structures.

All statistical analyses were conducted using Genstat 20th Edition (VSN International Ltd., Hemel Hempstead, UK).

\subsection{Kinetic coefficients of denitrification}

Estimating values of kinetic parameters is beneficial for predicting effluent concentrations under any operating conditions [16].

The change of $\mathrm{NO}_{3}$ stock in the water column of the wetland during the investigation $\left(d \mathrm{NO}_{3} / d t\right)$ equals the difference between $\mathrm{NO}_{3}$ sources $\left(\mathrm{NO}_{3}\right.$ input [in] and nitrification) and $\mathrm{NO}_{3}$ sinks $\left(\mathrm{NO}_{3}\right.$ output [out], denitrification, and uptake of $\mathrm{NO}_{3}$ [up] [mg/m²/d]) [26].

$\frac{d \mathrm{NO}_{3}}{d t}=$ in + nit - out - denit - up

where in $=\mathrm{NO}_{3}^{-}$input $\left(\mathrm{mg} / \mathrm{m}^{2} / \mathrm{d}\right)$, nit $=$ nitrification $(\mathrm{mg} /$ $\left.\mathrm{m}^{2} / \mathrm{d}\right)$, out $=\mathrm{NO}_{3}^{-}$output $\left(\mathrm{mg} / \mathrm{m}^{2} / \mathrm{d}\right)$, denit. = denitrification $\left(\mathrm{mg} / \mathrm{m}^{2} / \mathrm{d}\right)$ and up $=$ uptake of $\mathrm{NO}_{3}^{-}$by plant $\left(\mathrm{mg} / \mathrm{m}^{2} / \mathrm{d}\right)$.

The effect of the nitrification process and uptake of $\mathrm{NO}_{3}^{-}$by plants on the denitrification rate has been neglected by many researchers [27], reducing Eq. (4) to:

denit. $=$ in - out $-\frac{d \mathrm{NO}_{3}}{d t}$

The loss of nitrate in a vertical flow wetland treatment system follows the first order kinetic model (Eq. (6)), particularly when the influent nitrate concentration in the wastewater is about $100 \mathrm{mg} / \mathrm{L}[26,27]$.

$\frac{C_{e}}{C_{0}}=e^{-k_{T} t}$

$k_{T}=k_{20}(1.06)^{T-20}$

where $C_{e}=$ effluent $\mathrm{N}$ concentration $(\mathrm{mg} / \mathrm{L}), C_{0}=$ influent $\mathrm{N}$ concentration $(\mathrm{mg} / \mathrm{L}), k_{T}=$ removal rate coefficient at temperature $T^{\circ} \mathrm{C}(1 / \mathrm{d})$, and $k_{20}=$ removal rate coefficient at $20^{\circ} \mathrm{C}(1 / \mathrm{d})$.

\section{Results}

\subsection{Filter bed operating conditions}

Average influent temperature was $19.2^{\circ} \mathrm{C}$ and average effluent temperature was slightly lower at $18.1^{\circ} \mathrm{C}$, indicating slight ambient cooling over the course of the experiment.

Average influent pH levels were $7.5( \pm 0.2)$, and average effluent values were $7.8( \pm 0.4)$, indicating a slight rise in $\mathrm{pH}$ throughout the course of the experiments. Over most of the experimental period, $\mathrm{pH}$ values were optimal (7.0-7.5) for promoting denitrification [15].

Influent redox values in the feed wastewater averaged $194 \pm 1 \mathrm{mV}$. Effluent redox values were 30, 14, 24, -105, 22 and $-122 \mathrm{mV}$ for CONT, CONT + AS, SUC, SUC + AS, ETH and $\mathrm{ETH}+\mathrm{AS}$, respectively. Redox values $>100 \mathrm{mV}$ promote aerobic conditions and $<100 \mathrm{mV}$ promote anaerobic conditions [28]. The oxidation-reduction conditions for all columns were identical in the first week of the adaptation period and became completely anaerobic (highlighted values) at day 10 for SUC + AS and $\mathrm{ETH}+\mathrm{AS}$, and at days 15 and 17 for ETH and SUC, respectively, and at days 19 and 15 for CONT and CONT + AS, respectively (Table 3).

Table 2

Nitrate sucrose agar medium composition used in this study [40]

\begin{tabular}{|c|c|}
\hline Component & Mass or volume \\
\hline Tap water & $1,000 \mathrm{~mL}$ \\
\hline $\mathrm{NaNO}_{3}$ & $2 \mathrm{~g}$ \\
\hline $\mathrm{K}_{2} \mathrm{HPO}_{4}$ & $1 \mathrm{~g}$ \\
\hline $\mathrm{MgSO}_{4} \cdot 7 \mathrm{H}_{2} \mathrm{O}$ & $0.5 \mathrm{~g}$ \\
\hline $\mathrm{KCl}$ & $0.5 \mathrm{~g}$ \\
\hline $\mathrm{FeSO}_{4} \cdot 7 \mathrm{H}_{2} \mathrm{O}$ & Trace \\
\hline Sucrose & $30 \mathrm{~g}$ \\
\hline Agar & $15 \mathrm{~g}$ \\
\hline
\end{tabular}

Table 3

Redox values over the adaptation period

\begin{tabular}{lllllll}
\hline Time $(\mathrm{d})$ & CONT & CONT + AS & SUC & SUC + AS & ETH & ETH + AS \\
\hline 0 & 194 & 193 & 195 & 194 & 195 & 195 \\
1 & 174 & 160 & 166 & 149 & 164 & 144 \\
3 & 166 & 142 & 157 & 144 & 147 & 143 \\
5 & 160 & 142 & 145 & 142 & 146 & 143 \\
7 & 154 & 127 & 144 & 121 & 123 & 118 \\
9 & 147 & 113 & 133 & 109 & 115 & 104 \\
11 & 136 & 107 & 128 & 78 & 113 & 77 \\
13 & 122 & 101 & 116 & 10 & 98 & -65 \\
15 & 115 & 98 & 101 & -56 & -66 & -95 \\
17 & 107 & 91 & 88 & -90 & -104 & -116 \\
19 & 95 & 87 & 83 & -105 & & -122 \\
21 & 30 & 14 & 24 & & & -95 \\
\hline
\end{tabular}




\subsection{Nitrate nitrogen removal}

Nitrate decay curves for all treatments are presented in Fig. 2 with an influent concentration of $100 \mathrm{mg} / \mathrm{L}$. No significant statistical differences were observed between CONT and other treatments where organic $C$ sources were used.

A sequence of four statistical models was compared. The first fitted all three parameters in Eq. (3), $y_{0^{\prime}} b$ and $k$, the same for all six treatments, the second model allowed only different $y_{0}$ values for each treatment, the third allowed different $y_{0}$ and $b$ values and in the final fourth model all three parameters differ for each treatment, all fitted parameters are given in Table 4 . While fitting the models, the percentage variance was monitored and as expected it grew from $88 \%$ for the first model (reflecting a good curve selection and fit) to $93 \%$ for the final model. Most importantly, the significance of the change of the fit while increasing the different number of parameters for the treatment curves, as described above, was followed. In particular, there was a highly significant difference $(p<0.001)$ between the last two models where the parameter $k$ was fitted the same for all treatments (model 3 ) and different (model 4), explaining the pattern observed in Table 4, more precisely that the decay for treatment ETH is much higher than for the rest of the treatments.

The results suggest that different asymptote parameters $\left(y_{0}\right)$, different rate (linear) parameters $(b)$, and different nonlinear shape parameters $(k)$ are required to obtain the best model fit to the data. Additional analysis revealed that time and treatment are highly significant $(p<0.001)$ and their interaction is borderline significant, $(p=0.052)$. The latter can be attributed to the pattern observed in Fig. 2, where the dynamics of ETH treatment in time is different from the rest of the treatments. Moreover, five of the six treatments have similar rates of decay $(-0.01)$, with the ethanol treatment (ETH) having much higher rate of decay (-0.03; Table 4).

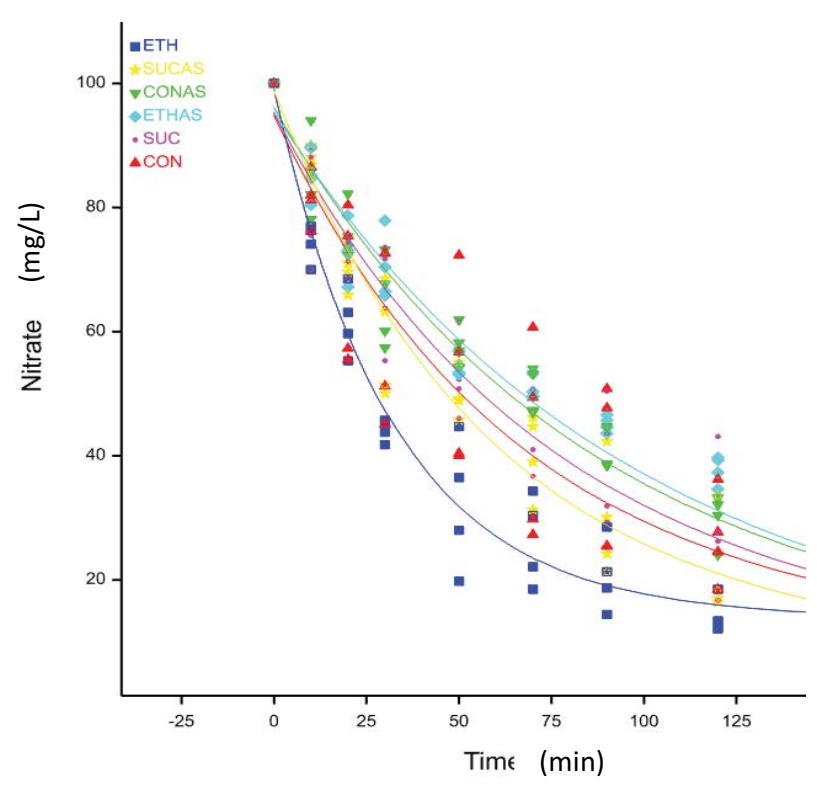

Fig. 2. Nitrate concentration decay over time.

\subsection{Nitrite production and decay}

Influent nitrite concentrations were $0,0,7,6,1$ and $0 \mathrm{mg} / \mathrm{L}$ for CONT, CONT + AS, SUC, SUC + AS, ETH, ETH + AS, respectively. Nitrite production and decay trends are shown in Fig. 3. Three comparative metrics can be obtained to describe the general dynamics: time to peak, peak concentration and reaction time. The latter were analysed statistically across treatments and the results are summarised in Table 5.

It can be seen that for the concentration peaks treatments SUC, SUC + AS, ETH and ETH + AS are significantly higher than the controls (with no significant difference between the CONT and CONT + AS peaks). At the same time, all SUC and ETH treatments with and without AS did not significantly differ from each other. Similarly, for the reaction time there was no significant difference between the CONT and CONT + AS but all SUC and ETH treatments had significantly longer reaction times. This reflects the increased production of nitrite compared with the controls and hence an increased time required for decay. There was no significant difference between ETH and SUC, but the addition of AS significantly reduced the reaction time for ETH and significantly increased the reaction time for SUC.

\subsection{COD removal}

The COD had an average influent concentration of 11, 62, 365, 433, 441 and $584 \mathrm{mg} / \mathrm{L}$ for CONT, CONT + AS, SUC, $\mathrm{SUC}+\mathrm{AS}, \mathrm{ETH}$ and ETH + AS, respectively. CONT and CONT + AS differed from the columns supplemented with external carbon sources (Fig. 4). The COD values for CONT and CONT + AS increased in the first $50 \mathrm{~min}$ of the experiment. At the end of the experiment, the average effluent

Table 4

Coefficient values

\begin{tabular}{lcl}
\hline Parameter & Estimate & Standard error (s.e.) \\
\hline$k$ Treatment CON & -0.015 & 0.002 \\
$b$ Treatment CON & 83.79 & 5.82 \\
$y_{0}$ Treatment CON & 11.01 & 6.43 \\
$k$ Treatment CON + AS & -0.012 & 0.002 \\
$b$ Treatment CON + AS & 87.55 & 8.82 \\
$y_{0}$ Treatment CON + AS & 8.540 & 9.79 \\
$k$ Treatment ETH & -0.031 & 0.003 \\
$b$ Treatment ETH & 85.04 & 3.68 \\
$y_{0}$ Treatment ETH & 13.94 & 2.75 \\
$k$ Treatment ETH + AS & -0.011 & 0.002 \\
$b$ Treatment ETH + AS & 89.50 & 10.2 \\
$y_{0}$ Treatment ETH + AS & 5.90 & 11.3 \\
$k$ Treatment SUC & -0.013 & 0.002 \\
$b$ Treatment SUC & 86.04 & 7.18 \\
$y_{0}$ Treatment SUC & 9.130 & 8.01 \\
$k$ Treatment SUC + AS & -0.017 & 0.002 \\
$b$ Treatment SUC + AS & 89.42 & 5.01 \\
$y_{0}$ Treatment SUC + AS & 9.380 & 5.41 \\
\hline
\end{tabular}




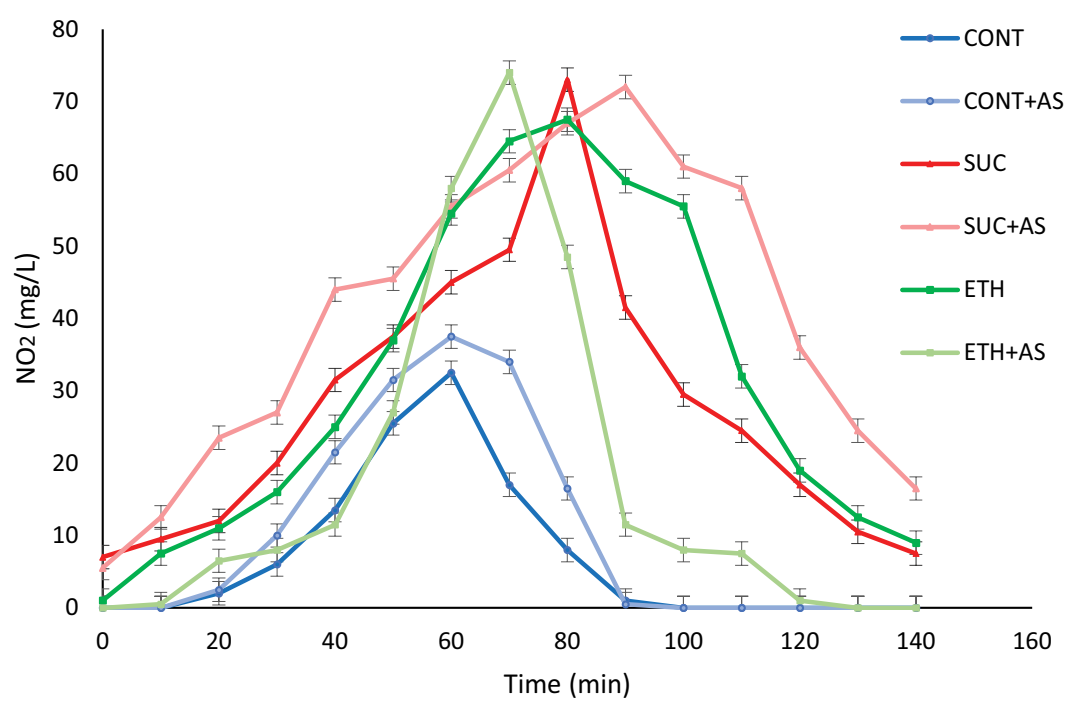

Fig. 3. Nitrite concentration over time.

\section{Table 5}

Metrics for nitrite accumulation across filter treatments: predicted means and LSD values

\begin{tabular}{lll}
\hline Columns & $\begin{array}{l}\text { Mean of peak } \\
\text { concentration }(\mathrm{mg} / \mathrm{L})\end{array}$ & $\begin{array}{l}\text { Mean of reaction } \\
\text { time }(\mathrm{min})\end{array}$ \\
\hline CONT & 32.5 & 80.0 \\
CONT + AS & 37.5 & 85.0 \\
SUC & 73.0 & 130.0 \\
SUC + AS & 72.0 & 145.0 \\
ETH & 67.5 & 135.0 \\
ETH + AS & 74.0 & 95.0 \\
LSD $(0.05)$ & 10.3 & 7.1 \\
\hline
\end{tabular}

COD values had declined to 1 and $11 \mathrm{mg} / \mathrm{L}$ for CONT and $\mathrm{CONT}+\mathrm{AS}$ treatments. Average effluent concentrations of COD for SUC, SUC + AS, ETH and ETH + AS were 48, 59,48 and $87 \mathrm{mg} / \mathrm{L}$, respectively. The biodegradation of organic matter mainly occurred in the first $50 \mathrm{~min}$ of the total time $(2.5 \mathrm{~h})$.

\subsection{Behaviour of denitrifying bacteria during the adaptation period}

Table 6 shows an increase in the bacterial population during the adaptation period, indicating successful growth of denitrifying bacteria before sampling commenced. The inoculated activated sludge was a mixture of autotrophic/heterotrophic bacteria from a wastewater

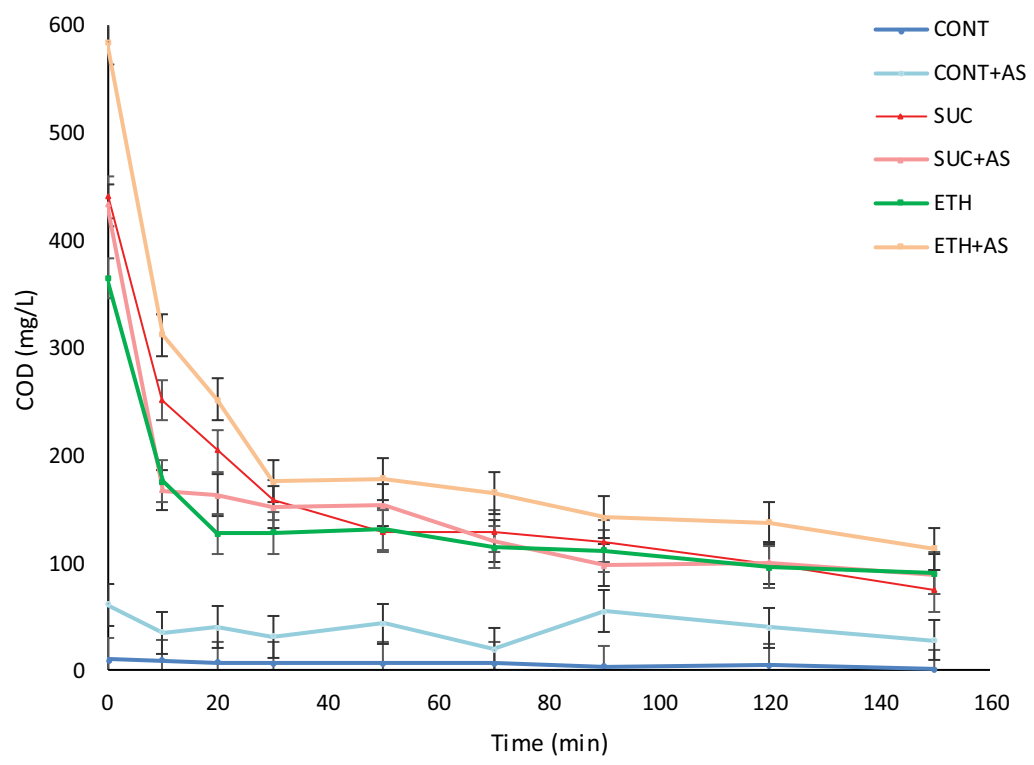

Fig. 4. COD concentrations over time. 
treatment plant. Bacterial counts on day 1 indicate that the addition of AS increased bacterial numbers for all treatments. By day 7 , the count numbers of all treatments were an order of magnitude higher than the control treatments. However, by day 21, count numbers had increased substantially in the controls, so that only the ETH + AS treatment had higher numbers. At the start of the experiment (after $21 \mathrm{~d}$ of recirculating the flow), the bacterial counts in the control equalled the sucrose treatments, and the CONT + AS treatment exceeded all but the ETH + AS treatment. All treatments, therefore, had active microbial populations of similar magnitude to the start of the experiment.

\section{Discussion}

\subsection{Operating conditions}

Eqs. (1) and (2) show that $575 \mathrm{mg} / \mathrm{L}$ of sucrose and $309 \mathrm{mg} / \mathrm{L}$ of ethanol are required to denitrify 1,000 mg/L of nitrate. Consequently, a lesser concentration of nitrate removal would be expected in the sucrose columns than in ethanol using the same quantity (concentration) of organic carbon (Fig. 2). Therefore, if ethanol is used instead of sucrose in the denitrification process, the amount added/ unit volume can be about half that of sucrose, using the same $\mathrm{C} / \mathrm{N}$ ratio.

The stoichiometric reactions (Eqs. (1) and (2)) demonstrate that the theoretical $\mathrm{C} / \mathrm{N}$ ratios should be 1.07 and 0.72 for sucrose and ethanol, respectively, for complete denitrification. However, Shah and Coulman [16] recommended a $\mathrm{C} / \mathrm{N}$ ratio of about 3 to maintain an adequate carbon source for complete elimination of inorganic nitrogen. In addition, in the case of a heterogeneous culture, the carbon source could be consumed by other microorganisms or by assimilation of the carbon source in the biofilm which is usually used for cellular growth [3]. Therefore, a $\mathrm{C} / \mathrm{N}$ ratio of 5 was chosen for this study to safely exceed the advised value.

Microbial growth and metabolic rates are strongly related to temperature [29], which can affect the performance of denitrifying bacteria [30]. Denitrification generally functions well at water temperatures from $15^{\circ} \mathrm{C}$ to $30^{\circ} \mathrm{C}[4,30]$ so we operated our system in this range.

In a filter matrix, the chemistry and biology of water are influenced by $\mathrm{pH}$ because healthy aquatic microorganisms can only function within a restricted $\mathrm{pH}$ range [31]. The results indicated a slight increase in $\mathrm{pH}$ level during the recirculation period as denitrification is an alkaline-producing process, consuming hydrogen ions and producing carbon dioxide. In theory, every $1,000 \mathrm{mg} / \mathrm{L}$ of $\mathrm{NO}_{3}^{-}$can consume $309 \mathrm{mg} / \mathrm{L}$ of ethanol and produce $820 \mathrm{mg} / \mathrm{L}$ of alkalinity as $\mathrm{HCO}_{3}$ (stoichiometric Eq. (2)).

Numerous researchers have reported that the dominant respiration activities and the related terminal electron acceptors, and hence elimination of nitrogen compounds are actively influenced by the prevailing oxidation-reduction potential (redox) in the filter bed matrix $[9,24,32,33]$. Therefore, redox can be a powerful tool for predicting the biological state of filters (e.g., aerobic, anoxic or anaerobic). Reddy and DeLaune [28] reported that the oxidation state of $\mathrm{N}$ compounds (from nitrate to nitrogen gas) in denitrification drops from +5 to 0 , as it is mediated by microbial activity, whereby facultative microbes acquire the enzymes that permit them to utilise nitrate, nitrite and nitrous oxide as the terminal electron acceptor during the oxidation of organic carbon under anoxic conditions. Although aerobic microbial growth is usually dominant [1], the presence of anoxic/anaerobic conditions (low redox values) in this study was observed during the adaptation period, which was due to the saturated conditions and selection of suitable substrate medium to promote microbial growth and denitrification $[9,16]$.

\subsection{Nitrate nitrogen removal}

Fig. 2 shows that the removal of $\mathrm{NO}_{3}$ was achieved efficiently at the top of the saturated zone as long as the anoxic conditions and microorganisms were maintained.

Under an initial nitrate concentration of $100 \mathrm{mg} / \mathrm{L}$, the average decay rate of nitrate for the CONT columns was $0.0118 / \mathrm{min}$, which is higher than values reported elsewhere $[34,35]$. Zaman et al. [35] studied nitrate removal in a wetland treating nitrate-rich wastewater without any addition of C sources. Their decay rates were $0.00174 / \mathrm{min}$ and $0.00255 / \mathrm{min}$ in surface and groundwater samples under initial nitrate concentrations of 1.5 and $8 \mathrm{mg} / \mathrm{L}$, respectively. Burchell et al. [34] studied enhanced nitrate removal by adding a dredged material as an organic C source into subsurface filters; their nitrate decay values for controls were $0.0000111,0.00004167,0.0000382$ and 0.0000354/ min across four investigation periods under initial nitrate concentrations of $30,40,60$ and $120 \mathrm{mg} / \mathrm{L}$, respectively, with a significant improvement in the performance of columns treated with organic matter relative to the control.

The initial recirculation in our study resulted in sufficient bacteria in the control for reasonably efficient decay, as there were no differences between most of the treatments. While many studies have investigated the effect of adding organic carbon on nitrate removal rate [6,12], we are not aware of any study that has compared the effect of adding commercial organic carbon sources sucrose and ethanol with the control on the performance of denitrification in filters.

As the growth of denitrifying bacteria is affected by the organic carbon contribution, and considering ethanol as the most appropriate carbon source [7], adding ethanol increased the rate of growth (Table 6) and the apparent decay rate (Fig. 2). The initial decline in nitrate with added ethanol was related to the reduced state of the organic source in the wastewater [36]. However, in the current study, the observed nitrate reduction with ETH + AS did not differ significantly from the controls or sucrose treatments, and only ETH produced a significantly higher decay rate. Makinia, 2010 [37] reported that only readily biodegradable compounds (including sucrose and ethanol) are considered substrates in heterotrophic growth under anoxic conditions. Thus, adding activated sludge may have hindered denitrification because the non-biodegradable compounds (particularly the soluble part) in wastewater cannot be easily metabolised by microorganisms [37]. Furthermore, the inoculated activated sludge was a mixture of autotrophic/ eterotrophic microorganisms from a wastewater treatment 
Table 6

Denitrifying bacteria growth over the recirculation period

\begin{tabular}{lllllll}
\hline & \multicolumn{5}{c}{ Denitrifying bacteria number $\left(\mathrm{CFU} \times 10^{4}\right)$} \\
\cline { 2 - 7 } Time $(\mathrm{d})$ & CONT & CONT + AS & SUC & SUC + AS & ETH & ETH + AS \\
\hline 1 & 0.01 & 0.002 & 0.06 & 0.3 & 0.023 & 0.04 \\
3 & 0.024 & 0.02 & 0.2 & 0.32 & 0.042 & 0.08 \\
5 & 0.2 & 0.06 & 0.8 & 0.98 & 0.54 & 0.2 \\
7 & 0.8 & 0.13 & 1.62 & 1.07 & 2.03 & 1.9 \\
14 & 2 & 3.43 & 2.2 & 2.1 & 8.208 & 10.02 \\
21 & 25.87 & 40.233 & 30.12 & 34 & 12.011 & 64 \\
\hline
\end{tabular}

plant. Hallin and Pell [14] confirmed that adding ethanol to the substrate media might affect the ability of denitrification to use other substances in the substrate rather than the external carbon sources. Andersson et al. [27] reported that adding an external $\mathrm{C}$ source alters the microbiology of the activated sludge due to the new biomass production, which changes the overall biocoenosis (an association of different organisms forming a closely integrated community) of the sludge. However, the selective effect of ethanol for very special groups of bacteria, which require ethanol for their growth, has not been well documented [27].

Rodriguez-Caballero et al. [15] studied the treatment efficiency of biological sand filters fed tap water (control), tap water + ethanol, and tap water + nutrients + ethanol. They reported that up to day 8 , the tap water + nutrients + ethanol treatment had similar enzyme activity as tap water + ethanol treatment; after which, it started to decline. To date, no investigation has compared sucrose and ethanol saturated with $\mathrm{N}$ compounds with and without activated sludge.

\subsection{Nitrite production and decay}

Nitrite accumulation in the denitrification process has been attributed to several factors including environmental conditions (abundance or lack of oxygen) [2], increased competition between nitrate and nitrite reductases for electrons $[3,38]$, and changes in the metabolism of competing bacteria [2]. In this study, the control columns had the lowest accumulation concentration peak relative to other columns (Fig. 3 and Table 5). Ge et al. [2] reported that the accumulation range increased when $C$ sources were added due to a shift in the microbial population (a temporary increase in nitrate respiratory bacteria that only reduce nitrate to nitrite compared with true denitrification bacteria that reduce nitrate to nitrite and then to nitrogen gas). The ETH + AS treatment had a faster decay rate of nitrite than the other treatments, which could be attributed to the competition of true denitrifiers over nitrate respirators [2]; this was also supported by the bacterial count data, with the highest denitrifying bacteria count in the ETH + AS treatment.

\subsection{COD removal}

COD is an indicator of the total organic fractionation of wastewater (readily + slowly + inert) [37]. The COD levels of CONT + AS initially accumulated and then declined.
Barnard and Meiring [36] affirmed that an increase in the COD removal rate is an indicator of the reduced state of organic compounds in wastewater due to a bacterial performance. Therefore, some accumulation of COD in the CONT + AS columns could be attributed to the bacterial limitation to oxidise the organic matter in the activated sludge. Christensson and Welander [39] attributed low COD removal to endogenous respiration in the column. An enhanced COD removal rate in the columns fed with the external carbon sources was observed (Fig. 4), which may be due to the presence of an electron acceptor (nitrate) and an electron donor (carbon source), that stimulates the simultaneous removal of COD and nitrate [15].

\subsection{Denitrifying bacteria behaviour}

Hallin et al. [23] used an activated sludge inoculum as the control and ethanol with activated sludge in a predenitrification activated sludge system with an average mixed liquor of 2,560 and 2,790 mg/L for control and ethanol treatments, respectively. The nitrogen removal efficiency with ethanol was approximately double that of the control after $12 \mathrm{~d}$ of adaptation. The authors attributed the rapid increase in denitrification rate with activated sludge fed ethanol to increased enzyme activity rather than altered bacterial species composition. Furthermore, Gomez et al. [13] concluded that the presence of various denitrifying bacteria might affect denitrification due to differences in the ability of these bacteria to reduce nitrate. In our study, denitrifying bacteria in the sludge might not be fully adapted to ethanol due to the incomplete availability of the particular microbial population that is necessary for metabolising ethanol $[27,40]$. The decline in the denitrification capacity of ethanol with added activated sludge may be due to a change in bacterial species composition, but this will not be evident in bacterial counts. Therefore, evaluation of the functional microbial community along with a taxonomic identification of the $16 \mathrm{~S}$ rDNA fragments to identify species of denitrifying bacteria is required.

\section{Conclusions}

Only the ethanol treatment significantly increased the rate of nitrate decay. This effect was suppressed when activated sludge was added with ethanol. For the control columns, the microbial population must have been 
sufficient to initiate nitrate decay. Therefore, there is a need to expand the research undertaken here to better define the role of ethanol (it might be carried with macrophytes) in enhancing nitrate loss from saturated sand filters and why activated sludge depresses this effect. In addition, using different $\mathrm{C} / \mathrm{N}$ ratios (lower and higher than the investigated ratio) for ethanol with different concentrations of activated sludge is recommended.

Overall, no nitrite was released from this system after $2.5 \mathrm{~h}$. At the end of the recirculation period, the ethanol columns had the lowest denitrifying bacteria count, but the ethanol with activated sludge columns had the highest denitrifying bacterial count. The enhanced nitrate decay with ethanol and suppression by addition of activated sludge suggests a possible shift in bacterial species rather than enzyme activity.

In the non-treated sand, the heterogeneous composition of activated sludge initially hindered COD removal. However, the addition of $\mathrm{C}$ sources resulted in an efficient COD removal, and no effect of activated sludge on COD removal was observed.

From a practical perspective, the increased nitrate decay rate observed with the addition of ethanol is of interest, as the volume of wastewater treated in a unit volume of filter material for nitrate decay doubled with ethanol compared with sucrose at the same concentration.

For denitrifying bacteria, analysis of the functional microbial communities involved in $\mathrm{N}$ removal and taxonomic identification of the $16 \mathrm{~S}$ rDNA fragments to identify species of denitrifying bacteria is recommended.

\section{References}

[1] L. Songliu, H. Hongying, S. Yingxue, Y. Jia, Effect of carbon source on the denitrification in constructed wetlands, J. Environ. Sci., 21 (2009) 1036-1043.

[2] S.Ge, Y. Peng, S. Wang, C. Lu, X. Cao, Y.Zhu, Nitrite accumulation under constant temperature in anoxic denitrification process: the effects of carbon sources and $\mathrm{COD} / \mathrm{NO}_{3}-\mathrm{N}$, Bioresour. Technol., 114 (2012) 137-143.

[3] C. Glass, J. Silverstein, Denitrification kinetics of high nitrate concentration water: $\mathrm{pH}$ effect on inhibition and nitrite accumulation, Water Res., 32 (1998) 831-839.

[4] C.G. Lee, T.D. Fletcher, G. Sun, Nitrogen removal in constructed wetland systems, Eng. Life Sci., 9 (2009) 11-22.

[5] L. Cui, Y. Ouyang, Q. Lou, F. Yang, Y. Chen, W. Zhu, S. Luo, Removal of nutrients from wastewater with Canna indica L. under different vertical-flow constructed wetland conditions, Ecol. Eng., 36 (2010) 1083-1088.

[6] P.B. Dhamole, S.F. D'Souza, S.S. Lele, A review on alternative carbon sources for biological treatment of nitrate waste, J. Inst. Eng., 96 (2015) 63-73.

[7] M.A. Gomez, J. Gonzalez-Lopez, E. Hontoria-Garcia, Influence of carbon source on nitrate removal of contaminated groundwater in a denitrifying submerged filter, J. Hazard. Mater., 80 (2000) 69-80.

[8] J.C. Lance, Effect of sludge additions on nitrogen removal in soil columns flooded with secondary effluent, J. Environ. Qual., 15 (1986) 298-301.

[9] P. Meng, H. Pei, W. Hu, Y. Shao, Z. Li, How to increase microbial degradation in constructed wetlands: influencing factors and improvement measures, Bioresour. Technol., 157 (2014) 316-326.

[10] R. Al-Saedi, K. Smettem, K.H.M. Siddique, The impact of biodegradable carbon sources on microbial clogging of vertical up-flow sand filters treating inorganic nitrogen wastewater, Sci. Total Environ., 691 (2019) 360-366.
[11] H. Constantin, M. Fick, Influence of C-sources on the denitrification rate of a high-nitrate concentrated industrial wastewater, Water Res., 31 (1997) 583-589.

[12] P. Dold, I. Takács Y. Mokhayeri, M. Nichols, J. Hinojosa, R. Riffat, C. Bott, W. Bailey, S. Murthy, Denitrification with Carbon Addition-Kinetic Consideration, Proceedings of Nutrient Removal Conference, The State of the Art, Water Environment Federation, Baltimore, Maryland, Vol. 80, 2008, pp. 417-427.

[13] M.A. Gomez, J.M. Galvez, E. Hontoria, J. Gonzalez-Lopez, Influence of ethanol concentration on biofilm bacterial composition from a denitrifying submerged filter used for contaminated groundwater, J. Biosci. Bioeng., 95 (2003) 245-251.

[14] S. Hallin, M. Pell, Metabolic properties of denitrifying bacteria adapting to methanol and ethanol in activated sludge, Water Res., 32 (1998) 13-18.

[15] A. Rodriguez-Caballero, J.B. Ramond, P.J. Welz, D.A. Cowan, Odlare, S.G. Burton, Treatment of high ethanol concentration wastewater by biological sand filters: enhanced COD removal and bacterial community dynamics, J. Environ. Manage., 109 (2012) 54-60.

[16] D.B. Shah, G.A. Coulman, Kinetics of nitrification and denitrification reactions, Biotechnol. Bioeng., 20 (1978) 43-72.

[17] H.D. Stensel, R.C. Loehr, A.W. Lawrence, Biological kintetics of suspended growth denitrification, J. Water Pollut. Control Fed., 45 (1973) 249-261.

[18] T.L. Ingersoll, L.A. Baker, Nitrate removal in wetland microcosms, Water Res., 32 (1998) 677-684.

[19] S.F. Moore, E.D. Schroeder, The effect of nitrate feed rate on denitrification, Water Res., 5 (1971) 445-452.

[20] A. Mohseni-Bandpi, D.J. Elliott, M.A. Zazouli, Biological nitrate removal processes from drinking water supply-a review, J. Environ. Health Sci., 35 (2013) 1-11.

[21] G. Langergraber, Modeling of processes in subsurface flow constructed wetlands: a review, Vadose Zone J., 2 (2008) 830-842.

[22] R. Al-Saedi, K. Smettem, K.H.M. Siddique, Nitrogen removal efficiencies and pathways from unsaturated and saturated zones in a laboratory-scale vertical flow constructed wetland, J. Environ. Manage., 228 (2018) 466-474.

[23] S. Hallin, C.F. Lindberg, M. Pell, E. Plaza, B. Carlsson, Microbial adaptation, process performance, and a suggested control strategy in a pre-denitrifying system with ethanol dosage, Water Sci. Technol., 34 (1996) 91-99.

[24] J.L. Faulwetter, V. Gagnon, C. Sundberg, Chazarenc, F. Burr, J. Brisson, A.K. Camper, O.R. Stein, Microbial processes influencing performance of treatment wetlands: a review, Ecol. Eng., 35 (2009) 987-1004.

[25] A.G. Rodina, Methods in Aquatic Microbiology, 1st ed., Baltimore, University Park Press, London, UK, 1972.

[26] S.C. Reed, D.S. Brown, Constructed wetland design - the 1st generation, Water Environ. Res., 64 (1992) 776-781.

[27] B. Andersson, U. Nyberg, H. Aspegren, Methanol and Ethanol as External Carbon Sources for Denitrification: Nitrogen Removal from Municipal Wastewater, Nordic Council of Ministers, Finland, 1995.

[28] K.R. Reddy, R.D. DeLaune, Biogeochemistry of Wetlands: Science and Applications, 1st ed., CRC, Taylor and Francis Group, Boca Raton, FL, 2008.

[29] T. Saeed, G. Sun, A review on nitrogen and organics removal mechanisms in subsurface flow constructed wetlands: dependency on environmental parameters, operating conditions and supporting media, J. Environ. Manage., 112 (2012) 429-448.

[30] P. Kuschk, A. Wiessner, U. Kappelmeyer, E. Weissbrodt, M. Kastner, U. Stottmeister, Annual cycle of nitrogen removal by a pilot-scale subsurface horizontal flow in a constructed wetland under moderate climate, Water Res., 37 (2003) 4236-4242.

[31] R.H. Kadlec, S. Wallace, Treatment Wetlands, 2nd ed., CRC Press, Boca Raton, FL, 2008.

[32] W.J. Mitsch, J.G. Gosselink, The value of wetlands: importance of scale and landscape setting, Ecol. Econ., 35 (2000) 25-33. 
[33] G. Sun, Y. Zhu, T. Saeed, G. Zhang, X. Lu, Nitrogen removal and microbial community profiles in six wetland columns receiving high ammonia load, Chem. Eng. J., 203 (2012) 326-332.

[34] M.R. Burchell, R.W.Skaggs, C.R. Lee, S. Broome, G.M. Chescheir, J. Osborne, Substrate organic matter to improve nitrate removal in surface-flow constructed wetlands, J. Environ. Qual., 36 (2007) 194-207.

[35] M. Zaman, M.L. Nguyen, A.J. Gold, P.M. Groffman, D.Q. Kellogg, R.J. Wilcock, Nitrous oxide generation, denitrification, and nitrate removal in a seepage wetland intercepting surface and subsurface flows from a grazed dairy catchment, Aust. J. Soil Res., 46 (2008) 565-577.

[36] J.L. Barnard, P.G.J. Meiring, Sources of hydrogen donors and their effects on denitrification rates, Prog. Water Technol., 8 (1977) 577-588.
[37] J. Makinia, Mathematical Modelling and Computer Simulation of Activated Sludge Systems, IWA Publishing, London, 2010.

[38] Z. Hu, J. Zhang, H.J. Xie, S.P. Li, J.H. Wang, T.T. Zhang, Effect of anoxic/aerobic phase fraction on $\mathrm{N}_{2} \mathrm{O}$ emission in a sequencing batch reactor under low temperature, Bioresour. Technol., 102 (2011) 5486-5491.

[39] M. Christensson, E. Lie, T. Welander, A comparison between ethanol and methanol as carbon sources for denitrification, Water Sci. Technol., 30 (1994) 83-90.

[40] B. Zhang, X. Xu, L. Zhu, Activated sludge bacterial communities of typical wastewater treatment plants: distinct genera identification and metabolic potential differential analysis, AMB Express, 8 (2018) 1-14. 